\title{
POST-TRANSCRIPTIONAL GENE SILENCING CONFERRED BY THE ECTOPIC EXPRESSION OF THE GRAPEVINE miRNA-g1 AND INHIBITION OF THE RESPONSE BY ANTI-miRNA-g1 INHIBITOR
}

\author{
VLADIMÍR REPKA ${ }^{1}$, MÁRIA ČARNÁ ${ }^{1,2}$ \\ ${ }^{1}$ Plant Production Research Center Piešt'any \\ ${ }^{2}$ Slovak University of Technology Bratislava
}

REPKA, V. - ČARNÁ, M.: Post-transcriptional gene silencing conferred by the ectopic expression of the grapevine miRNA-g1 and inhibition of the response by anti-miRNA-g1 inhibitor. Agriculture (Pol'nohospodárstvo), vol. 57, 2011, no. 4, pp. 137143.

Our results show that a subset (miRNA cluster 1) of grapevine (Vitis vinifera L., cv. Limberger) microRNAs (miRNAs) can be strongly induced by different apoptosis inducers including methyl jasmonate (MeJA), botrycin, cinerein and/or $\mathrm{H}_{2} \mathrm{O}_{2}$. We report here that the expression of endogenous miRNA-g1 and miRNA-g7 can be efficiently silenced in grapevine protoplasts using artificial miRNA (amiRNA) technology. Furthermore, we demonstrate that the ectopic expression of
amiRNAs (anti-mir miRNA-g1 and pre-mir miRNA-g1) designed to target a mature miRNA-g1 directs jasmonate-induced silencing against DAD1 protein (defender against death 1). These collective results strongly support the idea that a sub-population of grapevine miRNAs induced by apoptosis may function in one of the most critical defense systems for structural and mechanical fitness.

Key words: Vitis vinifera L., small RNA, gene silencing, protoplast, cell death, methyl jasmonate

Cytoplasmic control of mRNA degradation, translational repression and chromatin modification is one of the important strategies of eucaryotic gene expression programs. Cells have evolved a wide variety of gene silencing pathways mediated by small RNAs at the transcriptional, post-transcriptional and translational levels. Short interfering RNAs (siRNAs) and recently discovered microRNAs (miRNAs) are the most important regulators of gene expression at the post-transcriptional level. Moreover, these small (mostly 21 or $24 \mathrm{nt}$ in size), noncoding RNAs play crucial roles in eukarytotes by targeting mRNAs for silencing (Frizzi and Huang 2010). Silencing was triggered by expression of a transgene homologous to an endogenous gene, which resulted in the formation of long doublestranded RNA (ds-RNA; Fire et al. 1998; Hamilton and
Baulcombe 1999; Vance and Vaucheret 2001). The dsRNA trigger was cleaved into 22-25 nt RNAs which act as guides to target homologous mRNA sequences for destruction (Bernstein et al. 2001; Elbashir et al. 2001).

In plants, miRNAs are implicated in a plethora of diverse aspects of plant growth and development, including meristem establishment and maintenance, leaf morphology, abaxial-adaxial polarity, lateral root formation, stem and root growth, hormone signaling, flowering time, organ boundaries, floral organ identity and reproduction (Mallory and Vaucheret 2006; Sunkar et al. 2007). Several types of miRNAs are regulated in response to diverse stress conditions, which suggests that miRNA-directed post-transcriptional regulation of their respective target genes is important to cope

RNDr. Vladimír Repka, CSc., Research Institute of Viticulture and Enology, Plant Production Research Centre, Bratislava 833 11, Matúšková 25, Slovak Republic. E-mail: mysteriousman@szm.sk

Ing. Mária Čarná, Research Institute of Viticulture and Enology, Plant Production Research Centre, Bratislava 833 11, Matúšková 25, Slovak Republic and Slovak University of Technology, Bratislava 812 37, Radlinského 9, Slovak Republic. E-mail: carna@vurv.sk 
with the stress (Jones-Rhoades and Bartel 2004; Fujii et al. 2005; Chiou et al. 2006; Fahlgren et al. 2007; Sunkar et al. 2007; Shen et al. 2010; Qin et al. 2011). There is also a substantial body of evidence that specific miRNAs also play an important role in plant defense responses to pathogen attack (Gurr and Rushton 2005). Different experimental studies also indicates that miRNAs are key players in molecular pathways to resist plant pathogens; including virus-induced gene silencing (Kasschau et al. 2003; Chapman et al. 2004; Chen et al. 2004). A more detailed analysis performed by Navarro et al. (2006) clearly demonstrated that a plant miRNAs directly contributed to antibacterial resistance by repressing auxin signaling pathway.

In respect to the apoptosis and/or programmed cell death, there is only a few reports regarding the use of exogenous (synthetic) miRNAs and miRNA inhibitors in functional screening assays to identify miRNAs that affect this process in animals (e.g. bantam in Drosophila, Brennecke et al. 2003). In plants, a set of apoptosis-related miRNAs was, for the first time, observed and partially characterized only very recently (Repka 2008).

Specific miRNA function can be examined by up and down regulating specific miRNA levels to study endogenous or reporter gene regulation and phenotypic response. The microRNA functional analysis can be performed by using synthetic miRNA mimics (premiRNA precursors) and amiRNA inhibitors (anti-miRNA inhibitors) which are now commercially available for most known miRNAs. To address the more explicit role of the apoptosis-related grapevine miRNA cluster, in this work we have performed the post-transcriptional dadl gene silencing assay in situ using specific miRNA inhibitor and precursor.

\section{MATERIAL AND METHODS}

\section{Plant material}

Long-term cultivated callus cultures of grapevine (Vitis vinifera L., cv. Limberger) were used for all the experiments. These cultures were established and maintained basically according to Repka et al. (2000). Grapevine protoplast were prepared from cell suspension at the stationary growth phase. The cells were incubated in maceration solution containing $2 \%$ Macerase, $2 \%$ Cellulysin in buffer A (50 mM Mes-NaOH, pH
5.7 with $0.6 \%$ manitol) for a period of $8 \mathrm{~h}$. Then the protoplast were washed with fresh buffer A and immediately used for the electroporation experiment.

\section{Cells pre-treatment}

A stock solution $(5 \mathrm{mM})$ of methyl jasmonate (MeJA; Duchefa BV, Haarlem, The Netherlands) was first made up in absolute ethanol; various concentration of MeJA (0.05-50 $\mu \mathrm{M})$ were prepared by appropriate dilution in water and adjusted to the final concentration with $0.1 \%$ ethanol. Grapevine cell suspensions and/or isolated protoplasts were incubated with MeJA at concentration given at the text and $0.1 \%$ ethanol was applied as control. After the pre-treatment was completed, cells were harvested and immediately submerged in RNAlater ${ }^{\mathrm{TM}}$ solution (Ambion, Austin, TX, USA) for archival storage at $-20^{\circ} \mathrm{C}$.

Microscopy, cytochemistry, TUNEL and cell viability assays

Cell viability was determined cytochemically by staining of cells with solution containing fluorescein diacetate (FDA, $1 \mathrm{mg} \mathrm{cm}^{-3}$ ) and propidium iodide (PI, $1 \mathrm{mg} \mathrm{cm}^{-3}$ ) in sterile 24-well tissue culture plates (Nunc AS, Roskilde, Denmark) as described previously (Repka et al. 2001). The integrity of DNA in nucleus of control and treated cells was estimated with DAPI (4,6-diamidino-2-phenylindole, $0.1 \mathrm{mg} \mathrm{cm}^{-3}$ ) staining (Repka et al. 2001). Cytochemically-stained cells were observed under a LEICA DMIRB fluorescence microscope equipped with a LEICA DC 450 colour CCD camera (Leica, Wetzlar, Germany). The RAW data of digital images were processed with Adobe Photoshop CS3 software (Adobe, San José, CA, USA).

An in situ apoptosis detection kit Apo-Direct TUNEL (Calbiochem-Merck, Bratislava, Slovakia) was used to detect the nuclear DNA fragmentation according to the protocol provided by the manufacturer. The cells were permeabilized with Cytonin for $30 \mathrm{~min}$ at $18-24^{\circ} \mathrm{C}$ and then washed with DNase-free water $(2 \times 2 \mathrm{~min})$. Permeabilized cells were incubated at $37^{\circ} \mathrm{C}$ for $2 \mathrm{~h}$ with the reaction mixture containing terminal deoxynucleotidyltransferase $(\mathrm{TdT}), 1 \times$ incorporating buffer and fluorescein-dUTP and then were rinsed with $1 \times$ TdT Stop buffer $(2 \times 5 \mathrm{~min})$ to stop labeling reac-tion. The stained cells were observed as described above. The experimental positive and negative controls were the Apo-Direct-Nuclease-treated and untreated samples, respectively. 
Monitoring of gene silencing experiments and cell death rate detection were measured on the Agilent 2100 bioanalyzer (Agilent Technologies Inc., Cedar Creek, TX, USA) using a respective on-chip cell fluorescent kits provided fast and accurate results in an automated manner.

\section{Artificial miRNA (amiRNA) technology}

TAPIR, a web server designed for the prediction of plant microRNA targets (http://bioinformatics.psb. ugent.be/webtools/tapir; Bonnet et al. 2010) was efficiently used to design target mimics. Complementary functional analysis of respective miRNAs was performed using custom made synthetic miRNA mimics (anti-mir miRNA-g1 and pre-mir miRNA-g1; Ambion, Austin, TX, USA). Grapevine protoplasts were loaded with synthetic miRNA inhibitor and/or precursor using electroporation with the aid of the BTX-ECM830 electroporator (BTX Instruments, Holliston, MA, USA) following the manufacturer's protocol. The final electroporation volume used per experiment was $20 \mu \mathrm{l}$ containing $1.5-3 \times 10^{5}$ protoplasts $\mathrm{cm}^{-3}$.

\section{Isolation of total RNA and small RNA enrichment}

An aliquots (1 mg FW) from both, control (untreated) and elicitor-treated cells were immediately placed in sterile Eppendorf microtubes containing RNAlater ${ }^{\mathrm{TM}}$ solution (Ambion, Austin, TX, USA) for storage until RNA extraction was performed. Total RNA was extracted from the cells using the mirVana ${ }^{\mathrm{TM}}$ miRNA Isolation Kit (Ambion, Austin, TX, USA) according to the manufacturer's protocol. This kit also provides specific procedures to enrich small RNAs (LMM) from higher molecular mass (HMM) RNAs. Using a Nanodrop ND-1000 (Nanodrop Technologies, Willmington, DE, USA), the total RNA was assessed for quality and quantity and then stored at $-80^{\circ} \mathrm{C}$ until future use.

\section{Quantitative real-time PCR ( $q R T-P C R)$}

TaqMan $^{\mathrm{TM}}$ microRNA assay (Applied Biosystems, Foster City, CA, USA) was used to verify the expression of 22 identified grapevine miRNAs (Repka 2008). First, reverse transcription PCR (RT-PCR) was performed using the TaqMan ${ }^{\mathrm{TM}}$ microRNA reverse transcription kit (Applied Biosystems) and miRNA-specific stem-loop primers included in the kit. Briefly, 1 $\mu \mathrm{g}$ of total grapevine RNA was used to generate a single-stranded miRNA cDNA for each of the miRNAs listed in the text. RT-PCR conditions were followed according to the manufacturer's protocol supplied with the kit. Second, qRT-PCR and miRNA specific primers designed by using Vector NTI Advance ${ }^{\mathrm{TM}}$ software were used to verify the expression of identified grapevine miRNAs. The reactions were run on an Eppendorf Mastercycler $^{\mathrm{TM}}$ ep realplex ${ }^{2}$ qRT-PCR cycler (Eppendorf, Hamburg, Germany). Three biological replicates along with two technique replicates were conducted for each miRNA. Following qRT-PCR, differences in miRNA expression levels were assessed by analyzing the mean $C_{\mathrm{T}}$ values. Inner reference primers were also $18 \mathrm{~S}$ rRNA and a constitutively expressed grapevine $2 \mathrm{~S}$ albumine gene $V v A l b 1$ served as an internal reference gene throughout experimenting.

\section{Northern blotting}

For Northern blot analysis, aliquots containing 5 $\mu \mathrm{g}$ of total RNA were denatured in $2.5 \mathrm{M}$ formaldehyde, $6 \times \operatorname{SSPE}(6 \times \mathrm{SSPE}=900 \mathrm{mM} \mathrm{NaCl}, 60 \mathrm{mM}$ $\mathrm{NaH}_{2} \mathrm{PO}_{4}, 6 \mathrm{mM}$ EDTA, pH 7.7) at $60^{\circ} \mathrm{C}$ for $1 \mathrm{~h}$, fractionated on a $1.2 \%$ formaldehyde gel and transferred to a nylon membrane (NYTRAN N-13, Schleicher \& Schuell, Dassel, Germany). The membrane was washed, prehybridized and hybridized according to Repka et al. (2004).

Custom-made, gene-specific, synthetic oligonucleotide probes (MWG Biotech GmbH., Ebersberg, Germany), end-labelled with biotin were used in the experiment. Hybridization of the probes, posthybridization stringency washes and membrane blocking with BLOTTO-MF solution was performed following the previously published protocols (Repka et al. 2004). Membranes were then incubated in a solution containing a horseradish peroxidase-conjugated avidin D (Vector Labs., Burlingame, NJ, USA) in TBS buffer for 1 hour. Finally, the membranes were washed in TBS and the signal was visualized and processed using SIBA/ECL protocol as described for immunoblots.

\section{Immunoblotting}

For quantitative and rapid screening of the accumulation of DAD1 and actin (reference) protein, the SIBA/ECL protocol (Repka et al. 1996) was employed. Individual samples equivalent to $50 \mu \mathrm{g}$ of total proteins were separated using 12\% SDS-PAGE, transferred onto nitrocellulose membrane (PROTRAN BA$85,0.45 \mu \mathrm{m}$, Schleicher \& Schuell, Dassel, Germany), blocked with BLOTTO-MF solution, and immunodeco- 
rated for specific antigen using the protocol described in Repka et al. (2004). Antigen-antibody complexes were visualized using SuperSignal West Dura (Pierce, Rockford, USA) and enhanced chemiluminiscence (ECL) images were recorded on the Kodak Image Station 2000R (Kodak, Hemel Hempstead, UK).

\section{RESULTS AND DISCUSSION}

Using a global microarray expression profiling approach we have previously identified a grapevine miRNA cluster directly involved in the execution and regulation of apoptosis (Repka 2008). To further assessing the putative role of this apoptosis-related grapevine miRNA cluster, we perform the transcriptional gene silencing assay in situ. As shown in Figure 1 (top row), pretreatment of cells with $50 \mu \mathrm{M}$ MeJA for $60 \mathrm{~min}$ resulted in a profound programmed cell death (Fig. 1 A and B) accompanied by a DNA fragmentation to oligonucleosomal fragments revealed using the
TUNEL assay (Fig. 1 C). Ectopic expression of miRNA-g1 (Fig. 1 E - green fluorescence) blocked MeJA induced apoptosis since no signs either of protoplast condensation nor DNA fragmentation was observed in these cells (Fig. $1 \mathrm{D}$ and F), indicating that miRNA-g1 is directly involved in arresting of cell anti-apoptotic pathway. More interestingly, however, there must exist a coexpression of other miRNAs because pretreatment of grapevine cells with the anti-miRNA-g1 synthetic oligonucleotide inhibitor does block the apoptosis induced by methyl jasmonate (Fig. 1 G). As shown in Figures $1 \mathrm{H}$ (small rectangle) and I, miRNA-g1-antimiRNA-g1 inhibitor complex is colocalized in the cell nucleus thus just before the phase when miRNA-g1 attend the processing pathway.

There were observed similar trends in cell death if the quantitative monitoring of gene silencing using specific miRNAs and corresponding amiRNAs was performed (Fig. 2). Statistically significant $(\mathrm{P}<0.001)$ differences were observed in the viability between miRNA non-silenced and miRNA-silenced popula-

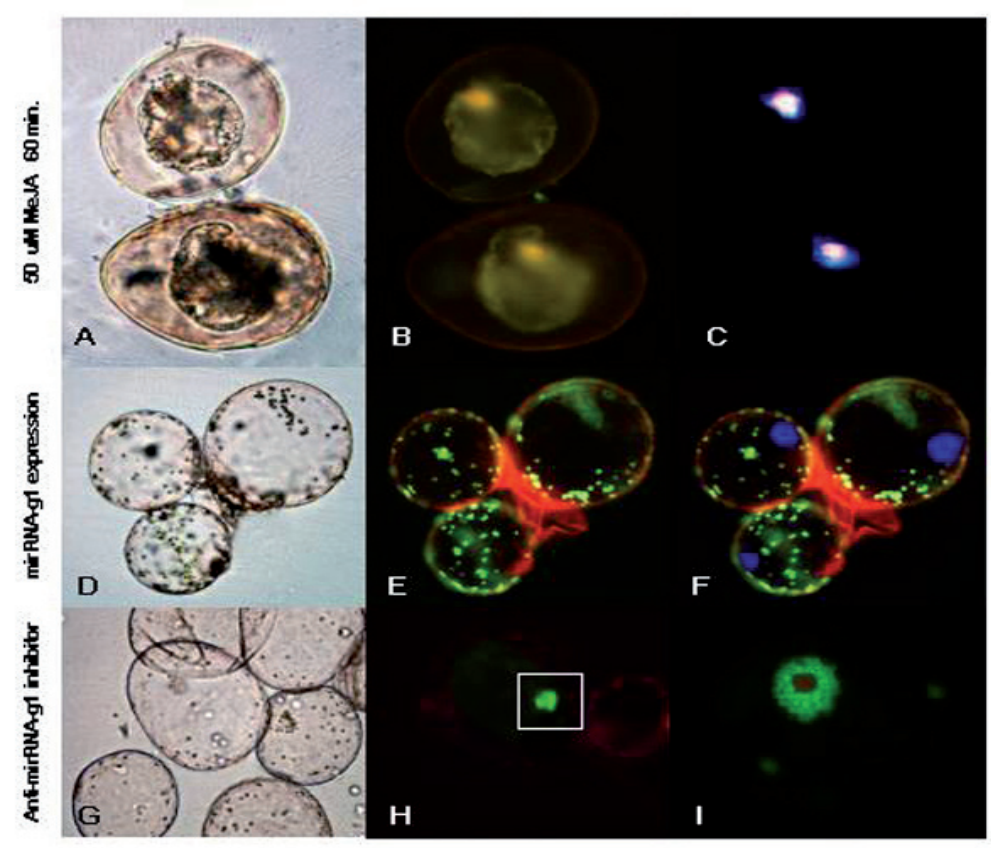

Fig. 1. Post-trancriptional gene silencing conferred by the ectopic expression of the grapevine miRNA-g1 and inhibition of the response by corresponding amiRNA inhibitor. Jasmo-nate induced cell death (A), protoplast collapse (B) and DNA fragmentation (C), and blocking of the respective events by the ectopic expression of miRNA-g1 (D, E, F). Attenuation of miRNA-g1 activity using synthetic anti-miRNA-g1 inhibitor $(\mathrm{G})$ and colocalization of the miRNA-g1-anti-miRNA-g1 inhibitor complex in the cell nucleus $(\mathrm{H})$. More precise in situ localization of the inhibitor complex in the nucleus (I) depicted by white square in figure $\mathrm{H}$

Bars represent $50 \mu \mathrm{m}$ 


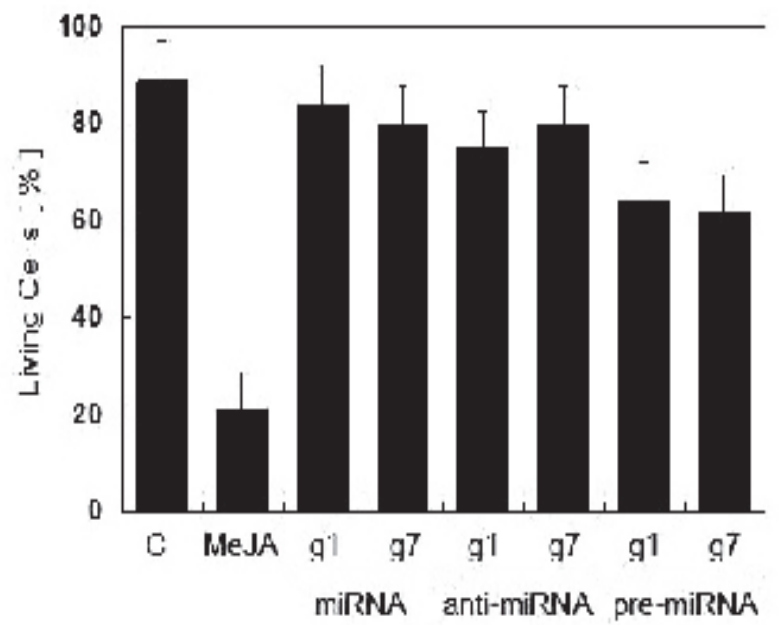

Fig. 2. The course of cell death execution in control (C), jasmonate-treated (MeJA), miRNA-silenced (miRNA), and amiRNA-transfected (anti-miRNA or pre-miRNA) populations of grapevine cells measured on the Agilent 2100 bioanalyzer. Bars represent

tions of grapevine cells.

To verify above assumption, we investigated whether RNA molecules modeled after miRNA precursor could enter the miRNA pathway and regulate translation. Ectopic expression of specific anti-miRNA inhibitors for miRNA-g1 and miRNA-g7 almost completely blocked corresponding targets. Also the synthetically created pre-miRNAs positively down-regulated corresponding miRNAs (Fig. 3 A). Similarly, Schwab et al. (2006) observed a highly specific gene silencing by artificial miRNAs (amiRNAs) in Arabidopsis. They examined the overexpression of amiRNAs designed to target single genes and found that amiRNA silencing resulted in robust and strong phenotypes that resembled those in plants with mutations in the respective target gene.

We also wanted to determine whether anti-miRNA and pre-miRNA inhibitors can regulate endogenous gene which expression is known to be modulated by miRNAs. Designed and created were synthetic precursors of miRNA-g1 and anti-miRNA-g1, known to regulate expression of DAD1 (defender against death $1)$.

DAD1 (Dolichyl-diphosphooligosaccharide-protein glycosyltransferase subunit), the defender against apoptotic cell death, was initially identified as a negative regulator of programmed cell death in the tem- perature sensitive tsBN7 cell line (Nakashima et al. 1993). The DAD1 protein disappeared in temperaturesensitive cells following a shift to the nonpermissive temperature, suggesting that loss of the DAD1 protein triggered apoptosis. DAD1 is believed to be a tightly associated subunit of oligosaccharyltransferase both in the intact membrane and in the purified enzyme (Kelleher and Gilmore 1997), thus reflecting the essential nature of N-linked glycosylation in eukaryotes (Makishima et al. 1997). In this context, it is important to note our earlier studies on the role of N-linked glycosylation in jasmonate-induced apoptosis in grapevine. Inhibition of N-linked glycosylation of specific protein, and perhaps DAD1, by tunikamycin, dramatically enhanced cell death in jasmonate-challenged grapevine cells (Repka 2001).

After the treatment of cell with MeJA, high miRNA-g1 resulted in lowering the DAD1 protein level
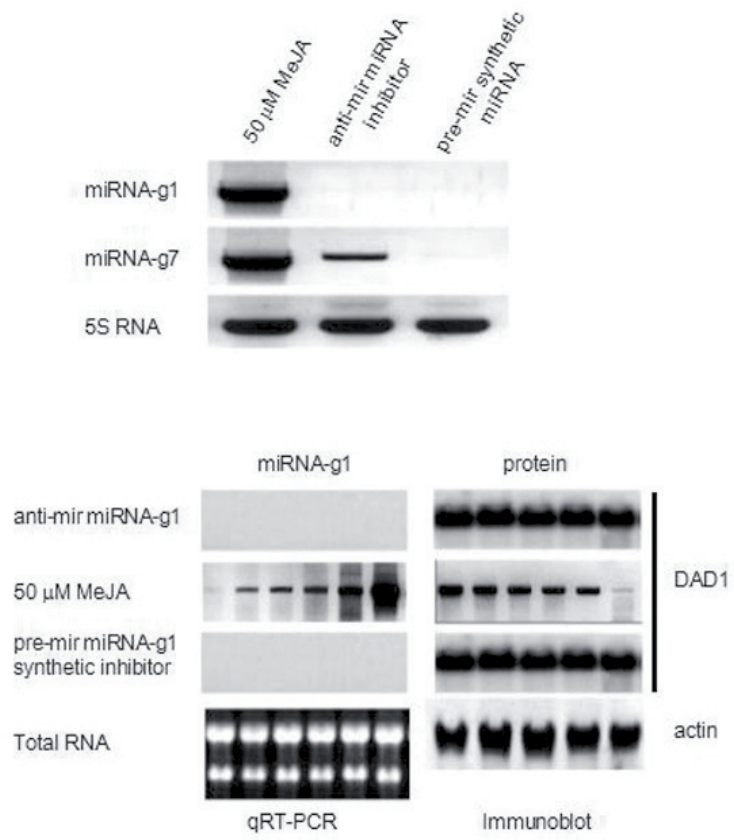

Fig. 3. Up- and down-regulation of miRNA-g1 and miRNA-g7 activity in grapevine cells using the synthetic inhibitors that modelled miRNA precursors and mature miRNAs A. Northern blot analysis of the inhibiton of target miRNAs by ectopic expression of specific amiRNA inhibitors

B. Modulated expression of the DAD1 protein by miRNA-g1 and synthetic amiRNA inhibitors analyzed using quantitative RT-PCR and immunoblot assays. A constitutively expressed actin gene was used as a control 
(Fig. 3 B, 50 uM MeJA). Inhibiting miRNA-g1 activity either with anti-miRNA-g1 or with pre-mir miRNA-g1 synthetic inhibitors (see "qRT-PCR" panel) resulted in constant DAD1 protein expression (see "Immunoblot" panel). Remarkably, Alvarez et al. (2006) have demonstarted that synthetic pre-miRNAs stimulated simultaneous, efficient, and localized regulation of multiple targets in diverse species. Synthetic miR-ARF targeting Auxin Response Factors 2, 3 and 4 induced dramatic transformation of abaxial tissues into adaxial ones in three plant species.

These collective results indicate that miRNA candidates of the 3 grapevine miRNA clusters are expressed and regulate gene targets directly involved in both apoptosis and defense response against pathogens.

\section{CONCLUSIONS}

In order to explore the extent and autonomy of gene downregulation that can be induced by miRNAs, we have chosen an experimental platform that uses sets of target genes for which complete conventional mutants does not exist.

Here, we also show that specific miRNAs can potentially abolish simultaneously the activities of all of their targets to levels matched by conventional loss-offunction mutations. Using ectopic expression of some grapevine miRNAs (miRNA-g1 and miRNA-g7) it was possible to reduce the apoptosis execution strongly induced by exogenous methyl jasmonate. This response could be functionally reversed by simultaneous addition of corresponding amiRNA inhibitor and/or precursor.

Consequently, our experiments with synthetic amiRNA inhibitor (anti-miRNA-g1) and precursor (pre-miRNA-g1) indicate that grapevine miRNA-g1 is directly involved in arresting of cell anti-apoptotic pathway probably via regulation of expression of DAD1 (defender against death 1) target protein. This observation might be important for future grapevine apoptosis and anti-apoptosis functional studies at the molecular and cellular levels.

Acknowledgements. The authors would like to thank Dr. T. Nishimoto (Tokio University, Japan) for a kind providing the antibodies against DAD1 pro- tein. This research work has been supported by a grant of the Slovak Ministry of Agriculture, contract No. 375/2010-510-K.

\section{REFERENCES}

ALVAREZ, J.P. - PEKKER, I. - GOLDSHMIDT, A. - BLUM, E. - AMSELLEM, Z. - ESHED, Y. 2006. Endogenous and synthetic microRNAs stimulate simultaneous, efficient, and localized regulation of multiple targets in diverse species. In Plant Cell, vol. 18, 2006, no. 5, pp. 1134-1151, DOI: $10.1105 /$ tpc. 105.040725

BERNSTEIN, E. - CAUDY, A.A. - HAMMOND, S.M. - HANNON, G.J. 2001. Role for a bidentate ribonuclease in the initiation step of RNA interference. In Nature, vol. 409, 2001, no. 6818, pp. 363-366

BONNET, E. - HE, Y. - BILliAU, K. - VAN DE PEER, Y. 2010. TAPIR, a web server for the prediction of plant microRNA targets, including target mimics. In Bioinformatics, vol. 12, 2010, no. 26, pp. 1566-8, DOI: 10.1093/bioinformatics/btq233

BRENNECKE, J. - HIPFNER, D.R. - STARK, A. - RUSSELL, R.B. - COHEN, S.M. 2003. Bantam encodes a developmentally regulated microRNA that controls cell proliferation and regulates the proapoptotic gene hid in Drosophila. In Cell, vol. 113, 2003, no. 1, pp. 25-36.

CHAPMAN, E.J. - PROKHNEVSKY, A.I. - GOPINATH, K. - DOLJA, V.V. - CARRINGTON, J.C. 2004. Viral RNA silencing suppressors inhibit the microRNA pathway at an intermediate step. In Genes \& Development, vol. 18, 2004, no. 10 , pp. 1179-1186.

CHEN, X. 2004. A microRNA as a translational repressor of APETALA2 in Arabidopsis flower development. In Science, vol. 303, 2004, no. 5666, pp. 2022-2025, DOI: $10.1126 /$ science. 1088060

CHIOU, T.J. - AUNG, K. - LIN, S.I. - WU, C.C. - CHIANG, S.F. - SU, C.L. 2006. Regulation of phosphate homeostasis by microRNA in Arabidopsis. In Plant Cell, vol. 18, 2006, no. 2, pp. 412-421, DOI: $10.1105 /$ tpc. 105.038943

ELBASHIR, S.M. - LENDECKEL, W. - TUSCHL, T. 2001. RNA interference is mediated by 21 and 22 nt RNAs. In Genes \& Development, vol. 15, 2001, no. 2, pp. 188-200.

FAHLGREN, N. - HOWELL, M.D. - KASSCHAU, K.D. - CHAPMAN, E.J. - SULLIVAN, C.M. - CUMBIE, J.S. GIVAN, S.A. - LAW, T.F. - GRANT, S.R. - DANGL, J.L. - CARRINGTON, J.C. 2007. High-throughput sequencing of Arabidopsis microRNAs: Evidence for frequent birth and death of miRNA genes. In The Public Library of Science, vol. 2, 2007, no. 2, pp. 219, DOI: 10.1371/journal.pone. 0000219

FIRE, A. - XU, S. - MONTGOMERY, M.K. - KOSTAS, S.A. - DRIVER, S.E. - MELLO, C.C. 1998. Potent and specific genetic interference by double-stranded RNA in Caenorhabditis elegans. In Nature, vol. 391, 1998, pp. $806-$ 811, DOI: $10.1038 / 35888$

FRIZZI, A. - HUANG, S. 2010. Tapping RNA silencing pathways for plant biotechnology. In Plant Biotechnology Jurnal, vol. 8, 2010, no. 6, pp. 655-677, DOI: 10.1111/j.1467- 
$7652.2010 .00505 . x$

FUJII, H. - CHIOU, T.J. - LIN, S.I. - AUNG, K. - ZHU, J.K. 2005. A miRNA involved in phosphate-starvation response in Arabidopsis. In Current Biology, vol. 15, 2005, no. 22, pp. 2038-2043.

GURR, S.J. - RUSHTON, P.J. 2005. Engineering plants with increased disease resistance: What are we going to express? In Trends in Biotechnology, vol. 23, 2005, no. 6, pp. 275-282.

HAMilton, A.J. - BAUlCOMBE, D.C. 1999. A species of small antisense RNA in posttranscriptional gene silencing in plants. In Science, vol. 286, 1999, no. 5441, pp. 950-952.

JONES-RHOADES, M.W. - BARTEL, D.P. 2004. Computational identification of plant MicroRNAs and their targets, including a stress-induced miRNA. In Molecular Cell, vol. 14, 2004, no. 6, pp. 787-799.

KASSCHAU, K.D. - XIE, Z. - ALlEN, E. - LLAVE, C. - CHAPMAN, E.J. - KRIZAN, K.A. - CARRINGTON, J.C. 2003. P1/HC-Pro, a viral suppressor of RNA silencing, interferes with Arabidopsis development and miRNA function. In Developmental Cell, vol. 4, 2003, no. 2, pp. 205-217.

KELLEHER, D.J. - GILMORE, R. 1997. DAD1, the defender against apoptotic cell death, is a subunit of the mammalian oligosaccharyltransferase. In Proceedings of the National Academy of Science of the USA, vol. 94, 1997, no. 10, pp. 4994-4999.

MAKISHIMA, T. - NAKASHIMA, T. - NAGATA-KUNO, K. - FUKUSHIMA, K. - IIDA, H. - SAKAGUCHI, M. - IKEHARA, Y. - KOMIYAMA, S. - NISHIMOTO, T. 1997. The highly conserved DAD1 protein involved in apoptosis is required for N-linked glycosylation. In Genes Cells, vol. 2, 1997, no. 2, pp. 129-141, DOI: 10.1046/j.13652443.1997.1070303.x

MALLORY, A.C. - VAUCHERET, H. 2006. Functions of microRNAs and related small RNAs in plants. In Nature Genetics, vol. 38, 2006, no. 7, pp. 31-36.

NAKASHIMA, T. - SEKIGUCHI, T. - KURAOKA, A. - FUKUSHIMA, K. - SHIBATA, Y. - KOMIYAMA, S. 1993. Molecular cloning of a human cDNA encoding a novel protein, DAD1, whose defect causes apoptotic cell death in hamster BHK21 cells. In Molecular and Celularl Biology, vol. 13, 1993, no. 10, pp. 6367-6374.

NAVARRO, B. - RUSSO, M. - PANTALEO, V. - RUBINO, L. 2006. Cytological analysis of Saccharomyces cerevisiae cells supporting cymbidium ringspot virus defective interfering RNA replication. In Journal of General Virology, vol. 87, 2006, no. 3, pp. 705-714.

QIN, Y. - DUAN, Z. - XIA, X. - YIN, W. 2011. Expression profiles of precursor and mature microRNAsunder dehydration and high salinity shock in Populus euphratica. In Plant Cell Reports, vol. 30, 2011, no. 5, pp. 1893-1907, DOI: $10.1007 / \mathrm{s} 00299-011-1096-9$

REPKA, V. 2008. Grapevine (Vitis vinifera L.) microRNA expression profiling with miRNA bioarrays: indications for an involvement of miRNA in apoptosis and pathogenesis. In Le Bulletin de L'OIV, vol. 81, 2008, no. 926-927-928, pp. 171-178.

REPKA, V. - FISHEROVÁ, I. - ŠILHÁROVÁ, K. 2004. Methyl jasmonate is a potent elicitor of multiple defense responses in grapevine leaves and cell-suspension cultures. In Biologia Plantarum, vol. 48, 2004, no. 2, pp. 273-283, DOI: 10.1023/B:BIOP.0000033456.27521.e5

REPKA, V. - FISHEROVÁ, I. - ŠILHÁROVÁ, K. 2001. Biological activity of the elicitor released from mycelium of a grapevine isolate of the necrotrophic fungus Botrytis cinerea. In Vitis, vol. 40, 2001, no. 4, pp. 205-212.

REPKA, V. 2001. Elicitor-stimulated induction of defense mechanisms and defense gene activation in grapevine cell suspension cultures. In Biologia Plantarum, vol. 44, 2001, no. 4, pp. 555-565, DOI: 10.1023/A:1013742703929

REPKA, V. - KUBÍKOVÁ, J. - FISHEROVÁ, I. 2000. Immunodetection of PR-1-like proteins in grapevine leaves infected with Oidium tuckerii and in elicited suspension cell cultures. In Vitis, vol. 39, 2000, no. 3, pp. 123-127.

REPKA, V. - FISHEROVÁ, I. - ČANIGOVÁ, K. 1996. Expression of cucumber stress-related anionic peroxidases during flower development or a cryptic infective process. In Biologia. Plantarum., vol. 38, 1996, no.4, pp. 585-596.

SCHWAB, R. - OSSOWSKI, S. - RIESTER, M. - WARTHMANN, N. - WEIGEL, D. 2006. Highly specific gene silencing by artificial microRNAs in Arabidopsis. In Plant Cell, vol. 18, 2006, no. 5, pp. 1121-1133, DOI: 10.1105/ tpc. 105.03983

SHEN, J. - XIE, K. - XIONG, L. 2010. Global expression profiling of rice microRNAs by one-tube stem-loop reverse transcription quantitative $\mathrm{PCR}$ revealed important roles of microRNAs in abiotic stress responses. In Molecular Genetics \& Genomics, vol. 284, 2010, no. 2, pp. 477-488.

SUNKAR, R. - CHINNUSAMY, V. - ZHU, J.H. - ZHU, J.K. 2007. Small RNAs as big players in plant abiotic stress responses and nutrient deprivation. In Trends in Plant Science, vol. 12, 2007, no. 7, pp. 301-309.

VANCE, V. - VAUCHERET, H. 2001. RNA silencing in plantsdefense and counterdefense. In Science, vol. 292, 2001, no. 5525, pp. 2277-2280.

Received: July, $7^{\text {th }}, 2011$ 